\title{
Neisseria macacae sp. nov., a new Neisseria Species Isolated from the Oropharynges of Rhesus Monkeys (Macaca mulatta)
}

\author{
NEYLAN A. VEDROS, ${ }^{*}$ CAROLYN HOKE, AND PETER CHUN \\ Naval Biosciences Laboratory, School of Public Health, University of California, Berkeley, California 94720
}

Three gram-negative, oxidase-positive diplococcal strains were isolated from the oropharynges of healthy monkeys. These three strains closely resembled Neisseria perflava in their physiological and biochemical characteristics, were more similar to Neisseria canis in their cellular fatty acid profiles, and were moderately related to Neisseria mucosa $(51.9 \%)$ as determined by deoxyribonucleic acid-deoxyribonucleic acid hybridization. An analysis of 11 enzymes indicated clustering closest to Neisseria sicca, followed by $N$. mucosa. We propose the name Neisseria macacae for this new species, and the type strain of this species is strain M-740 (= ATCC 33926).

Isolation of Neisseria species from animals other than humans has been well documented since the initial discussion of this subject in $\mathbf{1 9 5 3}$ (22). For example, Neisseria ovis has been isolated from sheep with keratoconjunctivitis (14); Neisseria animalis and Neisseria caviae have been isolated from guinea pigs (18); Neisseria canis has been isolated from dogs (3) and a cat bite wound in a child (12); Neisseria cuniculi, Neisseria mucosa, and Neisseria denitrificans have been isolated from rabbits or guinea pigs or both $(2,4)$; and $N$. mucosa has been isolated from cetaceans (25). The apparent broad host specificity of Neisseria spp. prompted us to study these bacteria in a variety of domestic and experimental animals. In this report we describe three similar isolates from the nasopharynges of rhesus monkeys (Macaca mulatta); these isolates represent a new species of Neisseria.

\section{MATERIALS AND METHODS}

Microorganisms. Three strains, designated strains $\mathrm{M}-738, \mathrm{M}-739$, and $\mathrm{M}-740^{\mathrm{T}}$ (type strain), were isolated from the oropharynges of monkeys ( $M$. mulatta), one each from three separate animals. The animals were being held in quarantine for approximately 3 weeks before release for experimental purposes. While each animal was sedated, its posterior nasopharynx was swabbed with a sterile Dacron swab slightly moistened with sterile saline, and the preparation was plated onto Mueller-Hinton agar (Difco Laboratories, Detroit, Mich.) containing 5\% defibrinated sheep blood and incubated at $37^{\circ} \mathrm{C}$ in a humid atmosphere containing $8 \% \mathrm{CO}_{2}$. Gram-negative, oxidase-positive diplococci were cloned onto Mueller-Hinton agar after $24 \mathrm{~h}$ of incubation. The pure cultures were preserved by lyophilization in Trypticase-soy broth (BBL Microbiology Systems, Cockeysville, Md.) containing $6 \%$ lactose and also stored in the same medium in capillary tubes at $-70^{\circ} \mathrm{C}$. To prepare organisms for tests, they were first cultured overnight on Mueller-Hinton agar at $37^{\circ} \mathrm{C}$ in a humid atmosphere containing $8 \% \mathrm{CO}_{2}$.
The reference strains of Neisseria species used in this study were $N$. mucosa ATCC $19696^{\mathrm{T}}, N$. canis ATCC $14678^{\mathrm{T}}, N$. ovis ATCC $19575^{\mathrm{T}}$, Neisseria perflava ATCC $10555^{\mathrm{T}}, N$. cuniculi ATCC $14688^{\mathrm{T}}, N$. denitrificans ATCC $146886^{\mathrm{T}}$, and Neisseria sicca NRL $30016^{\mathrm{T}}$. The reference strains were chosen to reflect a wide range of isolates from humans and animals. The sources of the type strains have been described previously $(10,11)$, and the strains were maintained and cultured as described above.

Morphological, biochemical, and physiological tests. The isolates were examined for pigment, irridescence, and colonial characteristics at 24-h intervals for 5 days by growing them on Mueller-Hinton agar at $37^{\circ} \mathrm{C}$ in a humid atmosphere containing $8 \% \mathrm{CO}_{2}$. Gram staining and tests for oxidase and catalase activities, hemolytic activity, optimum growth temperature, synthesis of polysaccharides from sucrose, degradation of deoxyribonucleic acid (DNA), reduction of nitrate and nitrite, and aminopeptidase activity were performed as previously described $(10,12)$. Degradation of tributyrin was determined on brain heart infusion agar (Difco) containing $0.01 \%$ tributyrin (Merck Sharp \& Dohme, West Point, $\mathrm{Pa}$.) (19). The cultures were incubated at $37^{\circ} \mathrm{C}$ in a humid atmosphere for 2 days and at $30^{\circ} \mathrm{C}$ for 3 days. A clear zone around the colonies was recorded as positive. Production of acid from sugars was determined by the rapid sugar fermentation test $(14,23)$ from cultures grown overnight at $37^{\circ} \mathrm{C}$ in a humid atmosphere on nutrient agar containing $0.5 \%$ glucose.

DNA base composition, fatty acid analysis, and DNADNA hybridization. The techniques used to study whole-cell fatty acid composition by gas-liquid chromatography, DNA base composition by measuring the DNA thermal denaturation midpoint, and DNA-DNA hybridization by spectrophotometry have been described previously $(10,11)$.

Enzyme analysis by electrophoresis. The enzymes analyzed were nicotinamide adenine dinucleotide phosphate-dependent glutamate dehydrogenase, leucine aminopeptidase, peroxidase, adenylate kinase, malic enzyme, reduced nicotinamide adenine dinucleotide diaphorase, glucose-6-phosphate dehydrogenase, isocitrate dehydrogenase, glutamate-oxaloace- 
tate transaminase, superoxide dismutase, and nicotinamide adenine dinucleotide-dependent glutamate dehydrogenase. The bacteria were grown overnight on Mueller-Hinton agar and inoculated (final concentration, approximately $10^{6}$ cells per $\mathrm{ml}$ ) into 250 $\mathrm{ml}$ of Trypticase-soy broth. The cultures were incubated for $6 \mathrm{~h}$ on a rotating shaking incubator at $37^{\circ} \mathrm{C}$ and $250 \mathrm{rpm}$, harvested by centrifugation at $10,000 \times \mathrm{g}$ for $15 \mathrm{~min}$, and suspended in $15 \mathrm{ml}$ of Hanks balanced salt solution ( $\mathrm{pH} 7.2)$. The cells were then ruptured in a model RF-1 Ribi Cell Fractionator (Ivan Sorvall, Inc., Norwalk, Conn.) at $20,000 \mathrm{lb} / \mathrm{in}^{2}$ and 5 to $10^{\circ} \mathrm{C}$. After rupture, the cell debris was removed by centrifugation at $20,000 \times g$ for $15 \mathrm{~min}$, and the supernatant was stored at $-20^{\circ} \mathrm{C}$ until it was tested.

Enzyme electrophoresis was performed on vertical gel slabs (14 by 12 by $0.1 \mathrm{~cm}$ ) by using the discontinuous buffer system described by Ornstein (17) and a model 500 apparatus (Hoefer Scientific Instruments, San Francisco, Calif.). A $10 \%$ acrylamide separation gel with a $5 \%$ acrylamide stacking gel was used for all of the enzymes studied except isocitrate dehydrogenase, for which a straight $5 \%$ acrylamide separation gel was used without a stacking gel. Electrophoresis was performed at a constant current of $30 \mathrm{~mA} / \mathrm{gel}$ slab at $4^{\circ} \mathrm{C}$ until the tracking dye bromophenol blue reached the bottom of the gel; $3 \mathrm{~h}$ was a typical run time. After electrophoresis, the gel slabs were removed, washed, and stained to visualize the enzymes as described by Harris and Hopkinson (9) and Shaw and Prasad (20).

Enzyme migrations were measured, and the relative mobilities were determined (relative mobility was the distance migrated by an enzyme divided by the distance migrated by the dye marker, which was usually the entire length of the gel). Similarity coefficients and relative taxonomic distances were determined by the unweighted pair group method of arithmetic mean, as described by Sneath and Sokal (21).

\section{RESULTS}

Morphological, physiological, and biochemical characteristics. The isolates from monkeys (strains M-738, M-739, and M-740 ${ }^{\mathrm{T}}$ ) had characteristics similar to those of $N$. perflava (Table 1), except the isolates from monkeys produced moderate hemolysis on horse blood agar and rabbit blood agar and their colonies were more firm and had a buttery consistency. N. mucosa reduced nitrate, did not degrade DNA, and was nonhemolytic, whereas the isolates from monkeys differed in these three characteristics. $N$. canis, which is representative of the true Neisseria isolated from animals $(5,23)$, reduced nitrate, had dry, wrinkled colonies, did not synthesize polysaccharides from sucrose, and showed variable hemolysis of rabbit erythrocytes. These characteristics differed from the characteristics of the isolates from monkeys, as did most of the characteristics of $N$. ovis, which is representative of isolates from animals that are currently considered to be false Neisseria (5, 24). The guanine-plus-cytosine contents of the isolates from monkeys, $N$. perflava, $N$. mucosa, and $N$. canis were in the range of values ( 48.9 to $53.4 \mathrm{~mol} \%$ ) which have been obtained for the

TABLE 1. Morphological, physiological, and biochemical characteristics of $N$. macacae strain $\mathrm{M}-740^{\mathrm{T}}$ and selected Neisseria species $^{a}$

\begin{tabular}{|c|c|c|c|c|c|c|}
\hline Test & $\begin{array}{l}\text { Strain } \\
\text { M-740 }\end{array}$ & N. perflava & $\begin{array}{c}N . \\
\text { sicca }\end{array}$ & N. mucosa & N. canis & N. ovis \\
\hline Yellowish pigment in colonies & $t^{b}$ & + & + & d & + & - \\
\hline Growth on $5 \%$ horse blood agar at $42^{\circ} \mathrm{C}$ & - & - & - & \pm & \pm & - \\
\hline \multicolumn{7}{|l|}{ Hemolytic activity } \\
\hline Horse blood & + & - & $\mathrm{d}$ & - & - & - \\
\hline Sheep blood & - & - & $\mathrm{d}$ & - & - & + \\
\hline Rabbit blood & + & - & $\mathrm{d}$ & - & $\mathrm{d}$ & + \\
\hline Human blood & - & - & $\mathrm{d}$ & - & - & + \\
\hline \multicolumn{7}{|l|}{ Production of acid from: ${ }^{d}$} \\
\hline Glucose & + & + & + & + & - & - \\
\hline Maltose & + & + & + & + & - & - \\
\hline Sucrose & + & + & + & + & - & - \\
\hline Fructose & + & + & + & + & - & - \\
\hline Nitrate test & - & - & - & + & + & + \\
\hline Nitrite test & $+(\mathrm{G})$ & $+(G)$ & $+(G)$ & $+(G)$ & - & - \\
\hline DNA hydrolyzed & + & + & - & - & - & - \\
\hline Tributyrin hydrolyzed & - & - & - & - & - & + \\
\hline Polysaccharide synthesized from sucrose & + & + & + & + & - & + \\
\hline
\end{tabular}

${ }^{a}$ In addition, the guanine-plus-cytosine contents of the DNAs were as follows: strain M-740 ${ }^{\mathrm{T}}, 50$ to $51 \mathrm{~mol} \%$; N. perflava, 49 to $50 \mathrm{~mol} \%$; N. sicca, 49 to $52 \mathrm{~mol} \% ; N$. mucosa, 51 to $52 \mathrm{~mol} \%$; N. canis, $50 \mathrm{~mol} \%$; and $N$. ovis, 45 to $46 \mathrm{~mol} \%$.

${ }^{b} \mathrm{~d}$, Variable within the species; + , positive reaction; \pm , slight or weak growth; $+(\mathrm{G})$, positive reduction with gas; - , negative reaction or no growth.

${ }^{c}$ All species grew on $5 \%$ horse blood agar at 30 and $37^{\circ} \mathrm{C}$.

${ }^{d}$ No acid was produced from mannitol or lactose by any of the species tested. 
TABLE 2. Cellular fatty acid analysis of $N$. macacae strain $\mathrm{M}-740^{\mathrm{T}}$ and selected Neisseria species

\begin{tabular}{llcr}
\hline \multicolumn{1}{c}{ Organism } & Major cellular fatty acids ${ }^{a}$ & $\begin{array}{c}\text { \% Of major fatty acids } \\
\text { with chain lengths } \\
\text { greater than } 16 \mathrm{C} \\
\text { atoms }\end{array}$ & $\begin{array}{c}\text { Ratio of } \mathrm{C}_{16} \text { fatty } \\
\text { acids to } \mathrm{C}_{18} \text { fatty } \\
\text { acids }\end{array}$ \\
\hline Strain M-740 & $12: 0,14: 0,16: 1,16: 0,18: 1$ & 8.3 & 9.0 \\
$N$. perflava & $12: 0,16: 0,16: 1,18: 1$ & 22.5 & 2.8 \\
N. mucosa & $12.0,16: 0,16: 1,18: 1$ & 21.6 & 3.9 \\
$N$. canis & $12: 0,14: 0,16: 1,16: 0,18: 1$ & 6.44 & 10.0 \\
N. ovis & $16: 0,17.0,17: 0,18: 0,18: 1$ & 70.81 & 0.2 \\
\hline
\end{tabular}

${ }^{a}$ Nomenclature: 12:0, lauric acid; 14:0, myristic acid; 16:0, palmitic acid; $16: 1$, palmitoleic acid; 18:0, stearic acid; $18: 1$, oleic acid.

true Neisseria (11), whereas the guanine-pluscytosine content of $N$. ovis was considerably lower (44.5 to $46.3 \mathrm{~mol} \%$ ).

Fatty acid analysis. Table 2 shows the result of an analysis of the cellular fatty acids of the isolates from monkeys (represented by strain $\mathrm{M}$ $740^{\mathrm{T}}$ ), $N$. perflava, $N$. mucosa, N. canis, and $N$. ovis. Strain M-740 ${ }^{\mathrm{T}}$ contained C12:0, C14:0, $\mathrm{C} 16: 0, \mathrm{C} 16: 1$, and $\mathrm{C} 18: 1$ as major fatty acids. This composition was similar to that of $N$. canis but differed from the major cellular fatty acid compositions of $N$. perflava, N. mucosa, and $N$. ovis. The percentages of major fatty acids with chain lengths greater than 16 carbon atoms and the ratio of $C_{16}$ fatty acids to $C_{18}$ fatty acids of strain $\mathrm{M}-740^{\mathrm{T}}(8.3 \%$ and 9.0 , respectively) were also more similar to the values for $N$. canis (6.44\% and 10.0, respectively) than the values for either $N$. perflava $(22.5 \%$ and 2.8 ), $N$. muco$s a(21.6 \%$ and 3.9$)$, or $N$. ovis (70.81 and 0.2$)$.

DNA-DNA hybridization. Table 3 shows the results obtained by hybridizing the DNAs of strain M-740 ${ }^{\mathrm{T}}$, strain M-739 and several selected Neisseria species. The highest degree of compatibility was observed between monkey strain M-740 ${ }^{\mathrm{T}}$ and strain M-739, followed by $N$. mucosa $(51.9 \%)$, and the lowest degree of compatibility was observed with $N$. canis $(25.1 \%)$. The

TABLE 3. DNA-DNA hybridization between $N$. macacae strain $\mathrm{M}-740^{\mathrm{T}}$ and $N$. macacae strain $\mathrm{M}$ 739 and selected Neisseria species

\begin{tabular}{|c|c|}
\hline Organism & $\begin{array}{l}\text { Degree of DNA binding } \\
\text { with strain } \mathrm{M}-740^{\mathrm{T}} \text { DNA }(\%)^{a}\end{array}$ \\
\hline Strain M-739 . . & 95 \\
\hline N. mucosa ..... & 52 \\
\hline N. ovis .............. & 42 \\
\hline N. cuniculi........... & 41 \\
\hline N. perflava........... & 36 \\
\hline N. denitrificans ......... & 31 \\
\hline N. canis ............. & 25 \\
\hline
\end{tabular}

${ }^{a}$ The values are the averages of three separate determinations. The standard deviations were $0.06 \pm$ $0.3 \%$. values for other species were intermediate $(N$. ovis, $42.1 \% ; N$. cuniculi, $40.6 \% ; N$. perflava, $35.7 \%$; and $N$. denitrificans, $31.4 \%$ ).

Aminopeptidase analysis. Strains M-738, 739, and $\mathrm{M}-740^{\mathrm{T}}$ all had gamma-glutamyl aminopeptidase, hydroxyproline aminopeptidase, arginine aminopeptidase, serine aminopeptidase, and glycyl-glycine aminopeptidase activities.

Enzyme electrophoresis. A representative gel pattern (isocitrate dehydrogenase) is shown in Fig. 1 . The relative mobilities or migration distances of all of the enzymes tested are shown in Table 4 . The similarity coefficients and a phenogram generated by unweighted pair group method of arithmetic mean clusterring are shown in Table 5 and Fig. 2, respectively. Strain M-740 clustered closest to $N$. sicca (similarity coeffi-

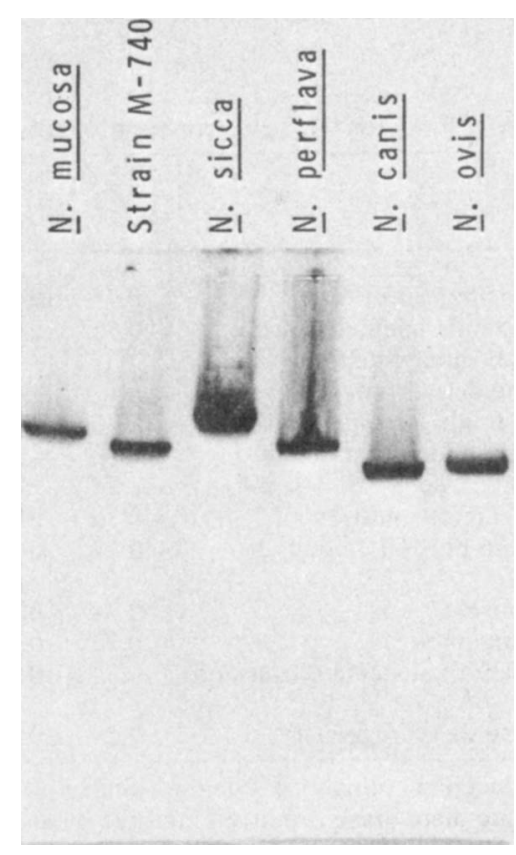

FIG. 1. Electrophoretic comparison of isocitrate dehydrogenases. 


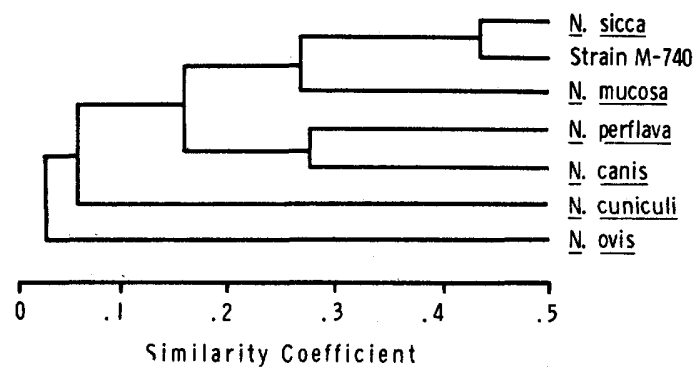

FIG. 2. Phenogram generated by unweight pair group method of arithmetic mean clustering.

cient, 0.442$)$, followed by $N$. mucosa $(0.294), N$. perflava $(0.219), N$. canis $(0.219), N$. ovis $(0.017)$, and $N$. cuniculi $(0.044)$.

\section{DISCUSSION}

There have been several reports that have indicated a much broader host range for Neisseria spp. than previously suspected $(6,24)$. Presumptive Neisseria spp. have been isolated from dental plaques of nonhuman higher primates, such as gorillas, orangutans, and patas monkeys (8). Many of these isolates produced acid from glucose, maltose, fructose, and sucrose and reduced nitrite with the production of gas and thus were similar to the strains described above. No genetic relatedness values and none of the other colonial, biochemical, and physiological characteristics used in this study were described. The isolates which we studied (strains M-738, M-739, and $\mathrm{M}-740^{\mathrm{T}}$ ) were first believed to be variants of $N$. perflava. The biochemical and physiological characteristics of these organisms were similar, except that $N$. perflava was nonhemolytic, whereas the monkey isolates showed moderate hemolysis of rabbit and horse erythrocytes ( $\mathrm{Ta}$ ble 1). Furthermore, the colonies of the monkey isolates had a different consistency than $N$. perflava colonies when they were cultured under similar conditions. An analysis of the cellular fatty acids indicated that the isolates from monkeys were very similar to $N$. canis rather than the other Neisseria species tested (Table 2). However, the procedure for fatty acid analysis which we used has been found previously (10) to be more useful for determining relatedness at the genus level than for determining relatedness at the species level.

Although transformation was not used in this study, DNA-DNA hybridization studies indicated that the isolates from monkeys were more closely related to $N$. mucosa $(51.9 \%$ compatibility) than to the other Neisseria species tested (Table 3). For example, the level of DNA relatedness between $N$. mucosa and strain $\mathrm{M}-740^{\mathrm{T}}$ (51.9\%) was lower than the level of relatedness between another isolate from animals, $N$. canis, and N. mucosa (54.2\% [10]).

There have been relatively few studies in which enzyme analysis by immunological or electrophoretic methods has been used to classify Neisseria spp. Nicotinamide adenine dinucleotide phosphate-dependent glutamate dehydrogenase from Neisseria meningitidis and malate

TABLE 4. Relative electrophoretic mobilities of the enzymes studied in various Neisseria species $^{a}$

\begin{tabular}{|c|c|c|c|c|c|c|c|}
\hline \multirow{2}{*}{ Enzyme } & \multicolumn{7}{|c|}{ Relative mobility in: } \\
\hline & N. mucosa & Strain $\mathrm{M}-740^{\mathrm{T}}$ & N. sicca & N. perflava & N. canis & N. ovis & N. cuniculi \\
\hline Adenylate kinase & 0.44 & 0.46 & 0.49 & 0.46 & 0.40 & 0.52 & 0.54 \\
\hline Leucine aminopeptidase & 0.31 & 0.31 and 0.41 & 0.31 & 0.26 & 0.31 & 0.40 & \\
\hline $\begin{array}{l}\text { Nicotinamide adenine dinucleo- } \\
\text { tide phosphate-dependent glu- } \\
\text { tamate dehydrogenase }\end{array}$ & 0.15 & 0.28 and 0.47 & 0.28 & 0.28 & 0.22 & 0.44 & \\
\hline $\begin{array}{l}\text { Nicotinamide adenine dinucleo- } \\
\text { tide-dependent glutamate de- } \\
\text { hydrogenase }\end{array}$ & 0.35 & 0.40 & 0.39 & 0.43 & 0.40 & 0.12 & 0.19 \\
\hline Superoxide dismutase & 0.36 & 0.70 & 0.49 & 0.49 & 0.49 & 0.54 & 0.43 \\
\hline $\begin{array}{l}\text { Glucose-6-phosphate dehydro- } \\
\text { genase }\end{array}$ & 0.27 & 0.25 & 0.25 & 0.30 & 0.26 & & 0.30 \\
\hline Peroxidase $^{b}$ & 0.34 & 0.47 & 0.50 & 0.50 & 0.50 & 0.55 & \\
\hline Malic enzyme & 0.22 & 0.22 & 0.20 & 0.25 & 0.32 & 0.33 & 0.34 \\
\hline $\begin{array}{l}\text { Glutamate-oxaloacetate transami- } \\
\text { nase }\end{array}$ & 0.34 & 0.31 & 0.33 & 0.36 & 0.28 and 0.32 & 0.40 & \\
\hline Isocitrate dehydrogenase & 0.29 & 0.31 & 0.27 & 0.31 & 0.35 & 0.35 & 0.26 \\
\hline
\end{tabular}

a Reduced nicotinamide adenine dinucleotide diaphorase and reduced nicotinamide adenine dinucleotide phosphate diaphorase produced multiple bands which were very complex (three to nine bands possible); hence, the electrophoretic mobilities of the individual bands are not included on the table.

$b$ There were a series of peroxidase activity bands with an electrophoretic mobility of 0.80 in all strains studied. 
TABLE 5. Coefficients of similarity between $N$. macacae strain $\mathrm{M}-740^{\mathrm{T}}$ and various Neisseria species

\begin{tabular}{|c|c|c|c|c|c|c|c|}
\hline \multirow{2}{*}{ Organism } & \multicolumn{7}{|c|}{ Similarity coefficient with: } \\
\hline & N. mucosa & Strain $\mathrm{M}-740^{\mathrm{T}}$ & N. sicca & N. perflava & N. canis & N. ovis & N. cuniculi \\
\hline N. mucosa & 1.0 & & & & & & \\
\hline Strain $\mathrm{M}-740^{\mathrm{T}}$ & 0.294 & 1.0 & & & & & \\
\hline N. sicca & 0.229 & 0.442 & 1.0 & & & & \\
\hline N. perflava & 0.038 & 0.219 & 0.283 & 1.0 & & & \\
\hline$N$. canis & 0.111 & 0.219 & 0.172 & 0.281 & 1.0 & & \\
\hline N. ovis & 0.017 & 0.017 & 0.017 & 0.017 & 0.100 & 1.0 & \\
\hline N. cuniculi & 0.049 & 0.044 & 0.083 & 0.033 & 0.033 & 0.0 & 1.0 \\
\hline
\end{tabular}

dehydrogenase from $N$. perflava were used to study the immunological distances among most Neisseria species. Anti-malate dehydrogenase serum did not distinguish among the true Neisseria strains, whereas anti-glutamate dehydrogenase separated the species into the following four groups with decreasing similarity to $N$. meningitidis: group I, which included $N$. meningitidis, Neisseria gonorrhoeae, Neisseria lactamica, Neisseria flavescens, and Neisseria cinerea; group II, which included $N$. sicca, $N$. perflava, Neisseria subflava subsp. flava, and $N$. subflava subsp. subflava; group III, which included N. mucosa; and group IV, which included Neisseria elongata. $N$. ovis, $N$. caviae, and Branhamella catarrhalis did not react with any serum (13). Other workers have analyzed the electrophoretic separation of unidentified soluble proteins $(8,16)$. Glucose-6-phosphate dehydrogenase and glutamate dehydrogenase were isolated from known Neisseria species, and their relative mobilities as determined by electrophoretic separation on cellogel strips were compared with the mobilities of enzymes from isolates from animals (8). Five isolates from nonhuman higher primates closely resembled $N$. mucosa in both of the enzyme mobilities mentioned above. In this study 11 enzymes were analyzed, and strain $\mathrm{M}-740^{\mathrm{T}}$ was compared with six Neisseria species (Table 4 and Fig. 2). The similarity coefficient between strain $\mathrm{M}-740^{\mathrm{T}}$ and $N$. sicca was 0.442 . In an extensive, on-going study of the enzyme patterns of all known Neisseria species (P. K. Chun, G. F. Sensabaugh, and N. A. Vedros, Abstr. Annu. Meet. Am. Soc. Microbiol. 1982, I75, p. 107), this similarity coefficient was almost identical to the similarity coefficients found among six $N$. perflava strains (0.440) and among $N$. sicca, $N$. mucosa, and $N$. perflava $(0.390$ to 0.410$)$. A determination of the significance of the similarity between the isolates from monkeys and $N$. sicca as shown by our enzyme analyses by electrophoresis awaits more detailed study. The positive reaction of strain-M-740 ${ }^{\mathrm{T}}$ for the aminopeptidases, particularly $\alpha$-glutamyl aminopeptidase, was similar to the reactions of $N$. perflava and $N$. mucosa, but interspecies variation was observed in the activities of these latter two species (10). This particular enzyme test is best suited for distinguishing $N$. meningitidis from $N$. gonorrhoeae $(7,12)$.

Based upon the findings discussed above, we propose that strains $\mathrm{M}-738, \mathrm{M}-739$, and $\mathrm{M}-740^{\mathrm{T}}$, which were isolated from rhesus monkeys, be placed in a new species, Neisseria macacae sp. nov. (ma'ca.cae. Portugese n. macaco female monkey; N.L. fem. gen. macacae of a monkey, referring to the source of the isolates).

Description of Neisseria macacae sp. nov. Gram-negative cocci occurring in pairs with adjacent sides flattened or singly; cells are nonmotile and 0.6 to $1.0 \mu \mathrm{m}$ in diameter.

Colonies on Mueller-Hinton agar or nutrient agar are slightly raised, yellowish green, and glistening, have entire edges, and are about 1 to $1.5 \mathrm{~mm}$ in diameter after $17 \mathrm{~h}$ of incubation at $37^{\circ} \mathrm{C}$ in a humid atmosphere.

Aerobic. Slight or no growth at 22 and $42^{\circ} \mathrm{C}$. Optimum growth at 35 to $37^{\circ} \mathrm{C}$; less growth at $30^{\circ} \mathrm{C}$. Growth enhanced by 5 to $8 \% \mathrm{CO}_{2}$ at 30 , 35 , or $37^{\circ} \mathrm{C}$. Moderate hemolysis of horse blood agar and rabbit blood agar.

Oxidase reaction with $1 \%$ tetramethyl-p-phenylenediamine hydrochloride is positive; catalase is produced; nitrate is not reduced; nitrite is reduced with the production of gas; polysaccharides are produced from sucrose; DNA is hydrolyzed; tributyrin is not hydrolyzed.

The guanine-plus-cytosine content of the DNA is 50 to $51 \mathrm{~mol} \%$.

Type strain: strain M-740 (= ATCC 33926).

\section{ACKNOWLEDGMENTS}

We thank Ulrich Berger for helpful advice and confirmation of several tests and Ron Giard and Hsiao-Lai Liu for technical assistance.

This research was supported by the Office of Naval Research Microbiology Program under contract N00014-81-C. 0570, NR 205-16 and by the Grossman Endowment Fund.

\section{LITERATURE CITED}

1. Berger, U. 1960. Neisseria animalis n. sp. Z. Hyg. Infektionskr. 147:158-161.

2. Berger, U. 1962. Uber das Vorkommen von Neisserien ber einigen Tieren. Z. Hyg. 148:445-457. 
3. Berger, U. 1967. Zur Systematik der Neisseria. Zentralbl. Bakteriol. Parasitenkd. Infektionskr. Hyg. Abt. 1 Orig. Reihe A 205:241-248.

4. Berger, U., and E. Paepcke. 1962. Untersuchungen uber die asaccharolytischen Neisserien des menschlichen Nasopharynx. Z. Hyg. 148:269-281.

5. Bøvre, K. 1980. Progress in classification and identification of Neisseriaceae based on genetic affinity, p. 55-72. In M. Goodfellow, and R. G. Boards (ed.), Microbiological classification and identification. Academic Press, Inc., New York.

6. Bøvre, K., and N. Hagen. 1981. The family Neisseriaceae: rod-shaped species of the genera Moraxella, Acinetobacter, Kingella and Neisseria and the Branhamella group of cocci, p. 1506-1529. In M. P. Starr, H. Stolp, H. G. Truper, A. Balows, and H. G. Schlegel (ed.), The procaryotes: a handbook on habitats, isolation, and identification of bacteria, vol. 2. Springer-Verlag, New York.

7. D'Amato, R. F., L. A. Eriquez, K. M. Tomfohrde, and E. Singerman. 1978. Rapid identification of Neisseria gonorrhoeae and Neisseria meningitidis by using enzymatic profiles. J. Clin. Microbiol. 7:77-81.

8. Dent, V. E. 1982. Identification of oral Neisseria species of animals. Appl. Bacteriol. 52:21-30.

9. Harris, H., and D. Hopkinson. 1976. Handbook of enzyme electrophoresis in human genetics. American Elsevier Publishing Co., New York.

10. Hoke, C., and N. A. Vedros. 1982. Taxonomy of the Neisseria: fatty acid analysis, aminopeptidase activity, and pigment extraction. Int. J. Syst. Bacteriol. 32:51-56.

11. Hoke, C., and N. A. Vedros. 1982. Taxonomy of the Neisseria: deoxyribonucleic acid base composition, interspecific transformation, and deoxyribonucleic acid hybridization. Int. J. Syst. Bacteriol. 32:57-66.

12. Hoke, C., and N. A. Vedros. 1982. Characterization of atypical aerobic, gram-negative cocci isolated from humans. J. Clin. Microbiol. 15:906-914.

13. Holten, E. 1974. Immunological comparison of NADP. dependent glutamate dehydrogenase and malate dehy- drogenase in genus Neisseria. Acta Pathol. Microbiol. Scand. Sect. B 82:849-859.

14. Kellogg, D. S., and E. M. Turner. 1973. Rapid fermentation confirmation of Neisseria gonorrhoeae. Appl. Microbiol. 25:550-552.

15. Lindquist, K. A. 1960 . Neisseria species associated with infectious keratoconjunctivitis of sheep. Neisseria ovis nov. spec. J. Infect. Dis. 106:162-165.

16. Noble, R., and S. C. Schell. 1978. Acrylamide gel electrophoresis of proteins of Neisseria gonorrhoeae as an epidemiological tool. Infect. Immun. 19:178-186.

17. Ornstein, L. 1964. Disc electrophoresis. I. Background and theory. Ann. N.Y. Acad. Sci. 121:321-349.

18. Pelczar, M. J., Jr. 1953. Neisseria caviae nov. sp. J. Bacteriol. 65:744.

19. Riou, J. Y. 1977. Diagnostic bacteriologique des espèces des genres Neisseria et Branhamella. Ann. Biol. Clin. 35:73-87.

20. Shaw, C. R., and J. Prasad. 1970. Starch gel electrophoresis of enzymes-a compilation of recipes. Biochem. Genet. 4:297-320.

21. Sneath, P. H. A., and R. R. Sokal. 1973. Numerical taxonomy: the principles and practices of numerical classification. W.H. Freeman, San Francisco.

22. Subcommittee on the Family Neisseriaceae. 1954. Minutes of meeting. Int. Bull. Bacteriol. Nomencl. Taxon. 4:95106.

23. Vedros, N. A. 1970 . Serology of the meningococcus, p. 293-314. In J. R. Norris and D. W. Ribbons (ed.), Methods in microbiology, vol. 9. Academic Press, Inc., New York.

24. Vedros, N. A. 1981. The genus Neisseria, p. 1499-1505. In M. P. Star, H. Stolp, H. G. Truper, A. Balows, and H. G. Schlegel (ed.), The prokaryotes: a handbook on habitats, isolation, and identification of bacteria, vol. 2. SpringerVerlag, New York.

25. Vedros, N. A., D. G. Johnston, and P. I. Warren. 1973. Neisseria species isolated from dolphins. J. Wildl. Dis. 9:241-244. 